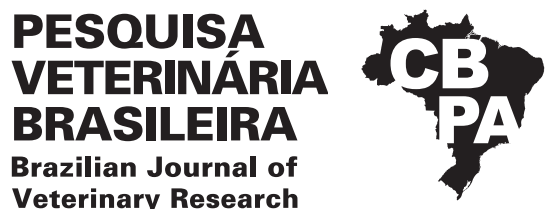

\title{
Pathological features of cloned calves that died in the neonatal period $^{1}$
}

\author{
Lídia dos Santos Pereira ${ }^{2}$, Mirna R. Porto ${ }^{2}$, Janildo L. Reis Júnior ${ }^{3}$, Rodolfo Rumpf ${ }^{4}$, \\ Edson R. Silva Júnior ${ }^{4}$, Benito Soto-Blanco ${ }^{5}$, Antônio Carlos L. Câmara ${ }^{2 *}$ (D) \\ and José Renato J. Borges ${ }^{2}$
}

\begin{abstract}
Pereira L.S., Porto M.R., Reis Júnior J.L., Rumpf R., Silva Júnior E.R., Soto-Blanco B., Câmara A.C.L. \& Borges J.R.J. 2020. Pathological features of cloned calves that died in the neonatal period. Pesquisa Veterinária Brasileira 40(11):852-862. Hospital Escola de Grandes Animais, Universidade de Brasília, Área Especial SRB, Galpão 4, Granja do Torto, DF 70636-200, Brazil. E-mail: aclcamara@yahoo.com.br

Somatic-cell nuclear transfer is a cloning technique that enables the creation of a viable embryo from a donor adult to produce a genetically identical individual. This technique opens numerous potential possibilities for medicine and animal reproduction. However, several reports have documented cloning-related issues. Embryo and fetal losses remain significantly higher than in other techniques, and there is a high incidence of dystocia and hydrops, which decreases efficiency and increases costs. Animals delivered at term often exhibit a syndrome known as macrosomia and experience difficulties in adapting to life outside the uterus, and death is a common outcome. In the present study, 41 cloned calves that died in the neonatal period were subjected to gross and histopathological examination. Most important gross lesions were found in the liver (enlargement, congestion, yellowish color), kidneys (brownish color at surface and cut, and cysts), lungs (atelectasis, parenchymal consolidation, and secretions in bronchi and bronchioles), and heart (concentric and eccentric hypertrophy, hematic cysts, persistence of ductus arteriosus). Primary microscopic findings were seen in the liver, kidneys, and lungs from neonatal calves. In the liver, 85\% of the animals exhibited hepatic degeneration. The presence of a brownish pigment within the cortical tubules of the kidneys was found in approximately $90 \%$ of the samples; the presence of this pigment has not been previously reported in cloned calves. In the lungs, a large number of animals exhibiting lesions characteristic of pneumonia (55\%). These changes were the pivotal causes of death, mainly due to problems in adapting to life outside the uterus and opportunistic infections in the neonatal period. Further investigation focusing on pathological anatomical changes is necessary to map these abnormalities in cloned animals.
\end{abstract}

INDEX TERMS: Neonatology, cattle, calf, clone, necropsy, histopathology.

RESUMO.- [Aspectos patológicos de bezerros clonados com óbito no período neonatal.] A transferência nuclear de células somáticas ou clonagem é uma técnica que permite produzir um indivíduo geneticamente igual a um outro indivíduo adulto. Esta técnica abre inúmeras possibilidades para a medicina e para a reprodução animal. Porém, existem

\footnotetext{
${ }^{1}$ Received on July $9,2020$.

Accepted for publication on July 24, 2020.

${ }^{2}$ Hospital Escola de Grandes Animais, Faculdade de Agronomia e Medicina Veterinária, Universidade de Brasília (UnB), Área Especial SRB, Galpão 4, Granja do Torto, DF 70636-200, Brazil.*Corresponding author: aclcamara@yahoo.com.br

${ }^{3}$ Departamento de Medicina Veterinária, Universidade Federal de Juiz de Fora (UFJF), Rua Espírito Santo 993, Juiz de Fora, MG 36010-041, Brazil.
}

inúmeros relatos de problemas associados à clonagem. A taxa de perda nos períodos embrionário e fetal ainda é muito alta quando comparada a outras biotécnicas; além disso, há uma maior incidência de hidropsias e distocias, diminuindo a eficiência e aumentando o custo da técnica. Os animais que vem a termo frequentemente apresentam

\footnotetext{
${ }^{4}$ Geneal Genética Animal - Análises, Pesquisa e Laboratórios S/A, BR-050 Km 184, Jardim Santa Clara, Uberaba, MG 38038-050, Brazil.

${ }^{5}$ Departamento de Clínica e Cirurgia Veterinárias, Escola de Veterinária, Universidade Federal de Minas Gerais (UFMG), Av. Pres. Antônio Carlos 6627, Belo Horizonte, MG 30123-970, Brazil.
} 
uma síndrome chamada de macrossomia, e apresentam dificuldades de adaptação à vida extrauterina e, por isso, o óbito é um desfecho comum. No presente trabalho realizou-se necropsia e coleta de fragmentos de órgãos para avaliação histopatológica de 41 bezerros com óbito neonatal. As lesões macroscópicas mais importantes foram encontradas no fígado (hepatomegalia, congestão e coloração amarelada), rins (coloração amarronzada na superfície e ao corte, e cistos), pulmões (atelectasia, parênquima consolidado, e secreções nos brônquios e bronquíolos), e coração (hipertrofia concêntrica e excêntrica, cistos hemáticos e persistência de ducto arterioso). As principais alterações microscópicas observadas foram presença de pigmento acastanhado no interior dos túbulos corticais renais (aproximadamente 90\% dos animais), degeneração hepática (85\% das amostras avaliadas) e lesões características de pneumonia (55\% dos animais). A pigmentação acastanhada no interior dos túbulos corticais é uma alteração que ainda não havia sido relatada anteriormente em animais clonados. As alterações observadas nestes órgãos foram determinantes para o óbito, e devem ter ocorrido sobretudo devido a problemas na adaptação ao ambiente extrauterino e em decorrência de infecções adquiridas no período neonatal. Os achados encontrados no presente trabalho denotam a necessidade de investigação anatomopatológica detalhada de animais clonados inviáveis, na tentativa de mapear as anormalidades apresentadas por eles.

TERMOS DE INDEXAÇÃO: Neonatologia, bovinos, bezerro, clone, necropsia, histopatologia.

\section{INTRODUCTION}

Despite advances in the field of somatic cell nuclear transfer (SCNT), especially in cattle, market growth continues to stumble due to the low efficiency of the cloning technique in producing viable offspring. Only $0.5 \%$ to $5 \%$ of reconstructed embryos produce term animals; this low success rate results in losses at the embryonic, fetal, and perinatal stages (Palmieri et al. 2008, Bressan et al. 2015, Ibtisham et al. 2017). It has been estimated that up to $80 \%$ of losses occur in the second month of pregnancies in SCNT animals; in contrast, such losses occur in only one-quarter of pregnancies from in vitro fertilization (Wiltbank et al. 2016).

It is believed that problems with placentation (placentomegaly, reduced vascularization of the chorioallantoid membrane, hypoplasia of the trophoblastic epithelium, and changes in the basement membrane) can result in significant losses during any gestational period (Lee et al. 2004, Palmieri et al. 2008, Barreto et al. 2009, Maiorka et al. 2015, Ao et al. 2019). Additionally, epigenetic reprogramming failures can lead to abnormal transcription of genes regulating implantation mechanisms, initial post-implantation development, and fetal growth. Such failures lead to a higher rate of late fetal losses, abnormalities observed in cloned calves (macrosomia, pulmonary hypertension, and neonatal asphyxia), and the highest rate of deaths in the neonatal period (Chavatte-Palmer et al. 2002, Lee et al. 2004, Kiefer et al. 2016).

Necropsy reports addressing cloned cattle are scarce, and those that are available only describe specific abnormalities (Birgel Junior et al. 2011, Maiorka et al. 2015). Moreover, the literature addressing the normal morphophysiology of newborn cattle is similarly scarce. Therefore, the present study aimed to describe pathological features of cloned (i.e., SCNT) calves that died in the neonatal period and to compare these with neonatal cattle of the same age group.

\section{MATERIALS AND METHODS}

Animals. This work was approved by the Ethics Committee on the Use of Animals (CEUA) of the Faculty of Agronomy and Veterinary Medicine of the University of Brasília (Brasília, Brazil), under process No. 2312/2013. Information regarding gestational length, calf age, and weight at death was collected. A total of 45 calves were evaluated, of which 41 were cloned that died in the neonatal period, and these were separated into two groups: Immediate Neonatal Group (ING), consisting of 25 cloned calves that died within the first 24 hours of life; and Late Neonatal Group (LNG), comprising 16 cloned calves that died between 2 and 28 days of life. All cloned calves are originated from Zebu breeds (subspecies Bos taurus indicus), from a commercial cloning company. The Control Group (CG) consisted of four male Girolando calves with age ranging from two to four days old. These animals were humanely euthanized using xylazine and thiopental (CFMV 2013) to compare pathological findings and verify whether such alterations are common to newborn cattle or are exclusive to cloned animals.

Necropsy and histological samples. The calves were subjected to necropsy immediately after spontaneous death (i.e., ING and LNG) or euthanasia (CG). Samples of the thoracic (heart and lungs) and abdominal (spleen, liver, and kidney) organs were fixed in 10\% buffered formaldehyde and subsequently subjected to routine histological processing. Hematoxylin and eosin (HE) standard staining was initially used for screening, and the slides were evaluated under a light microscope. After initial screening, liver and kidney samples were stained with Schiff's periodic acid (PAS). Kidney samples were also submitted to Hall staining to reveal bile pigments, Perls, for iron analysis; PAS staining for glycogen and lipofuscin; and Ziehl-Neelsen staining for lipofuscin. A comparative analysis of histological characteristics was performed among the three groups (i.e., ING, LNG, and CG).

\section{RESULTS}

The mean gestational age of the cloned calves was 290.5 days, being 289.9 days in ING and 291.5 days in LNG. The mean weight was $45.5 \pm 10.4 \mathrm{~kg}$, achieving $43.4 \mathrm{~kg}$ and $48.8 \mathrm{~kg}$ in ING and LNG, respectively (Table 1).

Main macroscopic findings are summarized in Table 2. Primary lesions were found in the liver (enlargement, congestion, yellowish color) (Fig.1A-B), kidneys (brownish color at surface and cut, and presence of cysts associated with cortical spinal rarefaction) (Fig.2A-B), lungs (atelectasis, parenchymal consolidation, and presence of varied secretions in bronchi and bronchioles) (Fig.3A-B), and heart (concentric and eccentric hypertrophy, presence of hematic cysts, and persistence of ductus arteriosus) (Fig.4A-B).

Main microscopic findings of the abdominal and thoracic organs are summarized in Table 3 and 4, respectively. In the liver, the most important changes included well-defined lobular pattern, virtually imperceptible sinusoids (both in $73 \%$ of cloned calves), closed distance between portal spaces (83\%), cytoplasmic vacuolization of hepatocytes (85\%) (Fig.1C-D), accumulation of glycogen (confirmed by PAS staining; 41\%), centrilobular necrosis with fibrin deposition, and inflammatory infiltrate (6\%). In the spleen, 
Table 1. Minimum and maximum values, mean and standard deviation of gestation length (days), age (days), and weight (kg) of cloned calves that died in the neonatal period

\begin{tabular}{|c|c|c|c|c|c|c|c|c|c|}
\hline \multirow{2}{*}{ Group } & \multicolumn{3}{|c|}{ Gestation length (days) } & \multicolumn{3}{|c|}{ Age (days) } & \multicolumn{3}{|c|}{ Weight (kg) } \\
\hline & Min & Max & Mean \pm SD & Min & Max & Mean \pm SD & Min & Max & Mean \pm SD \\
\hline ING $(n=25)$ & 272 & 308 & $289.9 \pm 8.69$ & 0 & 2 & $0.75 \pm 0.76$ & 23 & 59 & $43.4 \pm 9.92$ \\
\hline LNG $(n=16)$ & 278 & 303 & $291.5 \pm 8.39$ & 4.5 & 20 & $9.41 \pm 5.38$ & 23 & 67 & $48.8 \pm 10.5$ \\
\hline All calves $(n=41)$ & 272 & 308 & $290.5 \pm 8.51$ & 0 & 20 & $4.12 \pm 5.43$ & 23 & 67 & $45.5 \pm 10.4$ \\
\hline
\end{tabular}

$\mathrm{ING}=$ immediate neonatal group, $\mathrm{LNG}=$ late neonatal group, $\mathrm{Min}=$ minimum, $\mathrm{Max}=$ maximum, $\mathrm{SD}=$ standard deviation.

Table 2. Gross pathology findings in cloned and control calves that died in the neonatal period

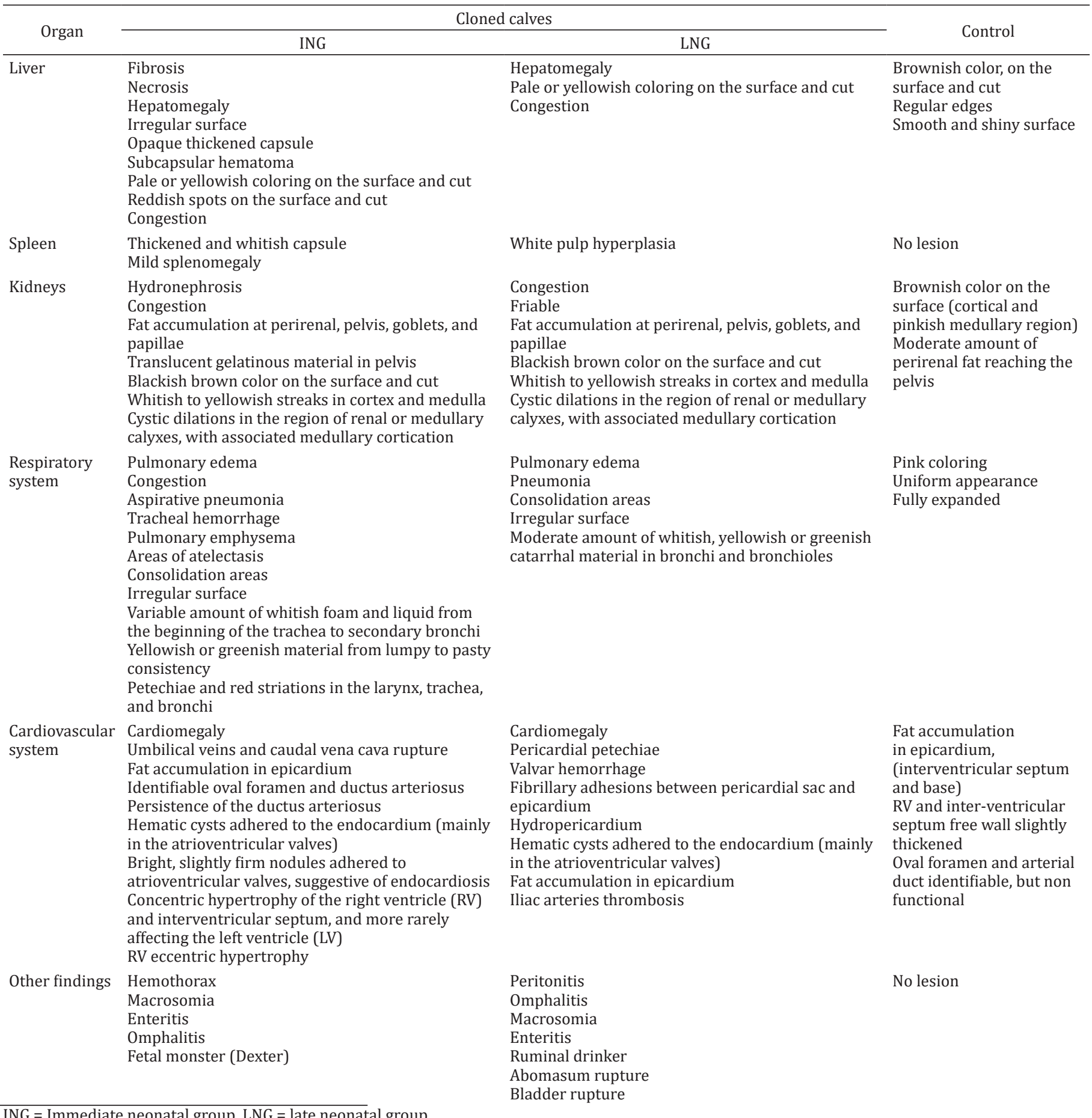


the most common finding was reduction in white pulp ( $48 \%$ of cases), evidenced by cellular rarefaction in lymphoid follicles. The kidneys exhibited smaller, hypercellular, and closer glomeruli (glomeruli with an embryonic aspect; 88\%) and brownish granules within the cortical tubule cells (90\%) (Fig.2C). After applying special stains (Hall, Perls, PAS, and Ziehl-Neelsen), only the lipofuscin stain labeled the observed granules, but not as characteristically as control fragments (Fig.2D). Inflammatory cell infiltration (55\% of cloned calves) (Fig.3C-D), atelectasis (45\%), and pulmonary edema (35\%) (Fig.3E) were the most common findings in the lungs. A yellowish amorphous substance (suggestive of meconium aspiration; 28\% of cases) (Fig.3C), and pinkish amorphous substance (suggestive of milk aspiration; 18\%) were also observed, most often associated with severe inflammatory infiltrate, indicating aspiration pneumonia. In the heart, there was a slight to moderate vacuolization of cardiac fibers (28\%), which appeared as round vacuoles that left the cell swollen (Fig.4C). Greater spacing between fiber bundles was also observed (45\%). In the CG, the same spacing of cardiac fiber bundles was observed, but at lower intensity (Fig.4D).

\section{DISCUSSION}

Dead cloned calves in the present study exhibited pathological changes in several organs. Main changes observed were the presence of a brownish pigment inside the renal cortical tubules (approximately $90 \%$ of cases), liver degeneration (85\% of evaluated samples), and lesions characteristic of pneumonia (55\% of animals). In fact, several reports have described congenital and acquired changes in cloned animals (Garry et al. 1996, Taneja et al. 2001, Rhind et al. 2003, Panarace et al. 2007, Santos et al. 2010, Maiorka et al. 2015). On the other hand, some studies did not find any alteration(s) at necropsy of cloned animals that died in the neonatal period (Wilmut et al. 1997, Kato et al. 1998, Lee et al. 2004). This absence of changes may be related to acute anoxia, which may explain the apparent lack of findings in many necropsies (Mee 2011). Additionally, neonatal deaths are often associated with respiratory problems, especially in depressed and long-standing calves (Wilson et al. 1995, Garry et al. 1996). Respiratory distress is believed to be the most common sign in calves that died without any other abnormalities (Panarace et al. 2007).

In the present study, the livers of cloned calves exhibited an irregular surface and a thickened and opaque capsule, which have also been previously described (Hill et al. 1999).
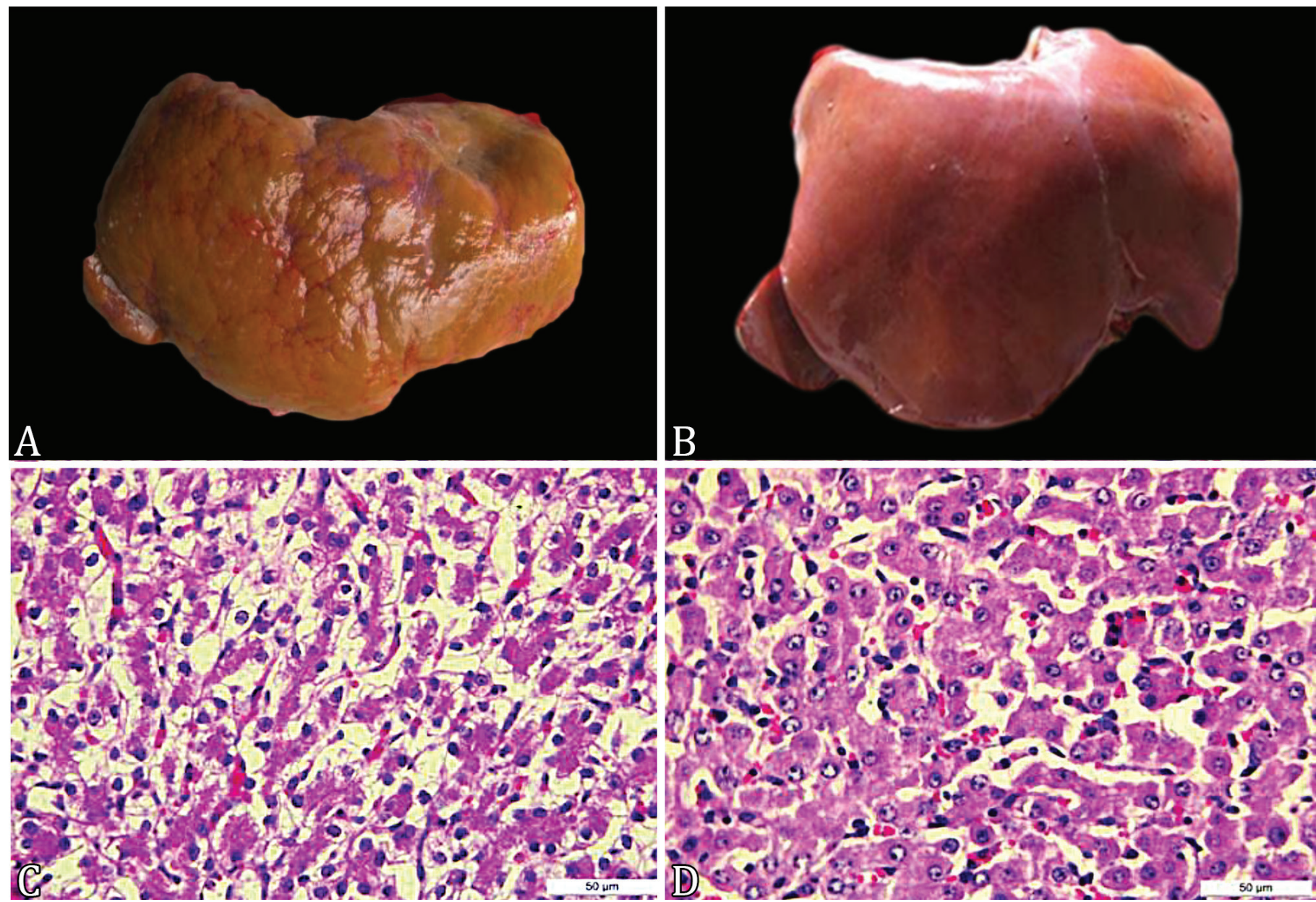

Fig.1. Changes observed in the liver of cloned and control neonates. (A) Irregular liver surface, cloned calf. (B) Normal liver, control animal.

(C) Marked hepatocyte vacuolization, cloned bovine. HE, obj.40x. (D) Discrete bovine hepatocyte vacuolization, control calf. HE, obj.40x. 
Subcapsular hematoma was observed in only one calf; however, there was no apparent explanation for its appearance and no correlation with other specific changes was found. Congestion and hepatic hemorrhage were observed in four animals under microscopy. The occurrence of hepatic congestion in cloned bovine neonates has been previously reported (Santos et al. 2010, Maiorka et al. 2015), indicating that this is a common finding in these animals. In control calves, the occurrence of hepatic congestion can be attributed to the agent used for euthanasia (thiopental) (Thomson 1998). The observation of hepatomegaly and hepatic steatosis, together with microscopic findings, revealed that vacuolated hepatocytes to varying degrees in cloned calves, however, more accentuated in ING animals, can be interpreted as fatty degeneration (due to the morphology of the vacuoles and macroscopic findings). Fatty degeneration has been attributed to the contribution of fat greater than the metabolism or the reduction in synthesis of proteins and lipoproteins involved in the transport of lipids out of the cell. It occurs in animals in starvation or severe food restriction, and also in other situations such as poisonings, ketosis in ruminants, and those with diabetes mellitus (Thomson 1998).
In the CG, some degree of hepatic fatty degeneration and areas of central-lobular necrosis were also observed; however, the intensity of injury was less severe compared with cloned calves. Fatty degeneration, enhancement of the lobular pattern, and central-lobular necrosis can be associated with hypoxia and death (Thomson 1998). In cloned sheep fetuses, hepatic degeneration suggests that the cause of such abnormalities is due to the lack of placental nutrition (De Sousa et al. 2001), as observed in several cloned calves, mainly from the ING. These changes were prominent in clones of advanced age, which may indicate liver regeneration in response to enteral feeding and independence from placental nutrition. The presence of hepatocyte vacuolization in the liver of bovine fetuses (Okano et al. 2003) and bovine neonates from in vitro fertilization (Prestes et al. 2009) has also been reported. It can be inferred, therefore, that some degree of hepatocyte vacuolization is normal in newborn animals. However, moderate to severe degeneration(s) can be interpreted as abnormal findings.

Okano et al. (2003) attributed hepatic vacuolization to the accumulation of glycogen in aborted animals, confirmed by PAS staining. Although hepatic glycogen was found in some animals, which is considered to be normal in mild to moderate amounts (Thomson 1998), a pathological finding (i.e., significant amount)
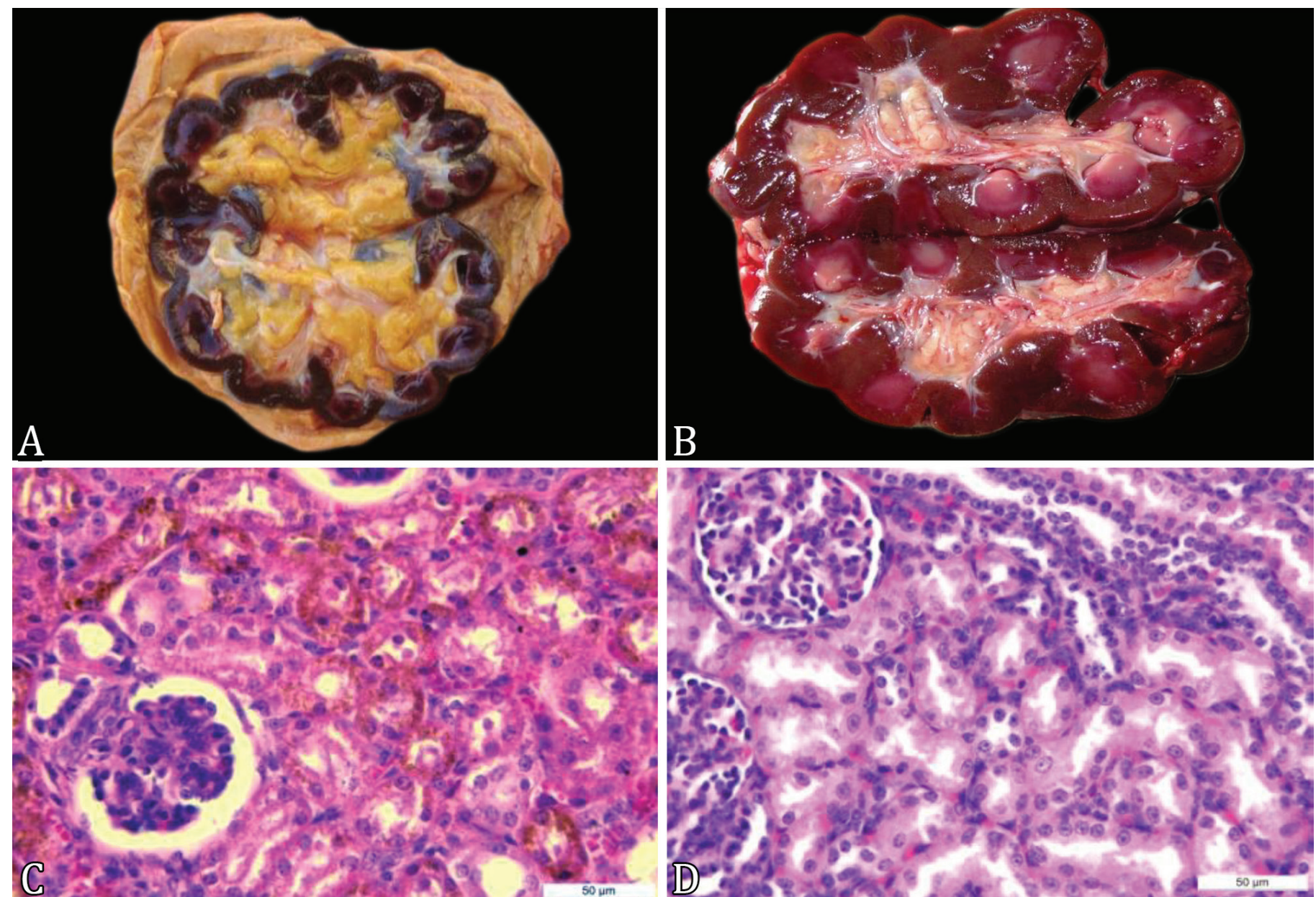

Fig.2. Changes observed in the kidneys of cloned neonates and controls. (A) Marked amount of perirenal fat, as well as in the pelvis, goblets, and renal papillae, brownish-black color of the renal cortex, cloned calf. (B) Kidney without changes, control calf. (C) Presence of brownish granules in the cytoplasm of tubules of the renal cortex, cloned calf. HE, obj.40x. (D) Normal appearance of the renal cortical tubules, control calf. HE, obj.40x. 
was present in 8 of 41 cloned and 1 of 4 control calves. It was found that changes in DNA methylation patterns in cloned cattle can interfere with hepatic metabolism, leading to changes in glycogen storage and fatty acid composition (Kiefer et al. 2016). It is mainly due to changes in genes, such as TCF7L2, in which polymorphisms have been associated with the development of type 2 diabetes. In fact, in the present investigation and several previous studies, moderate to severe fat deposition was observed in various tissues (Chavatte-Palmer et al. 2002, Santos et al. 2010, Maiorka et al. 2015).

In the spleen of cloned animals, macroscopic findings included mild splenomegaly and thickening of the capsule. Regarding
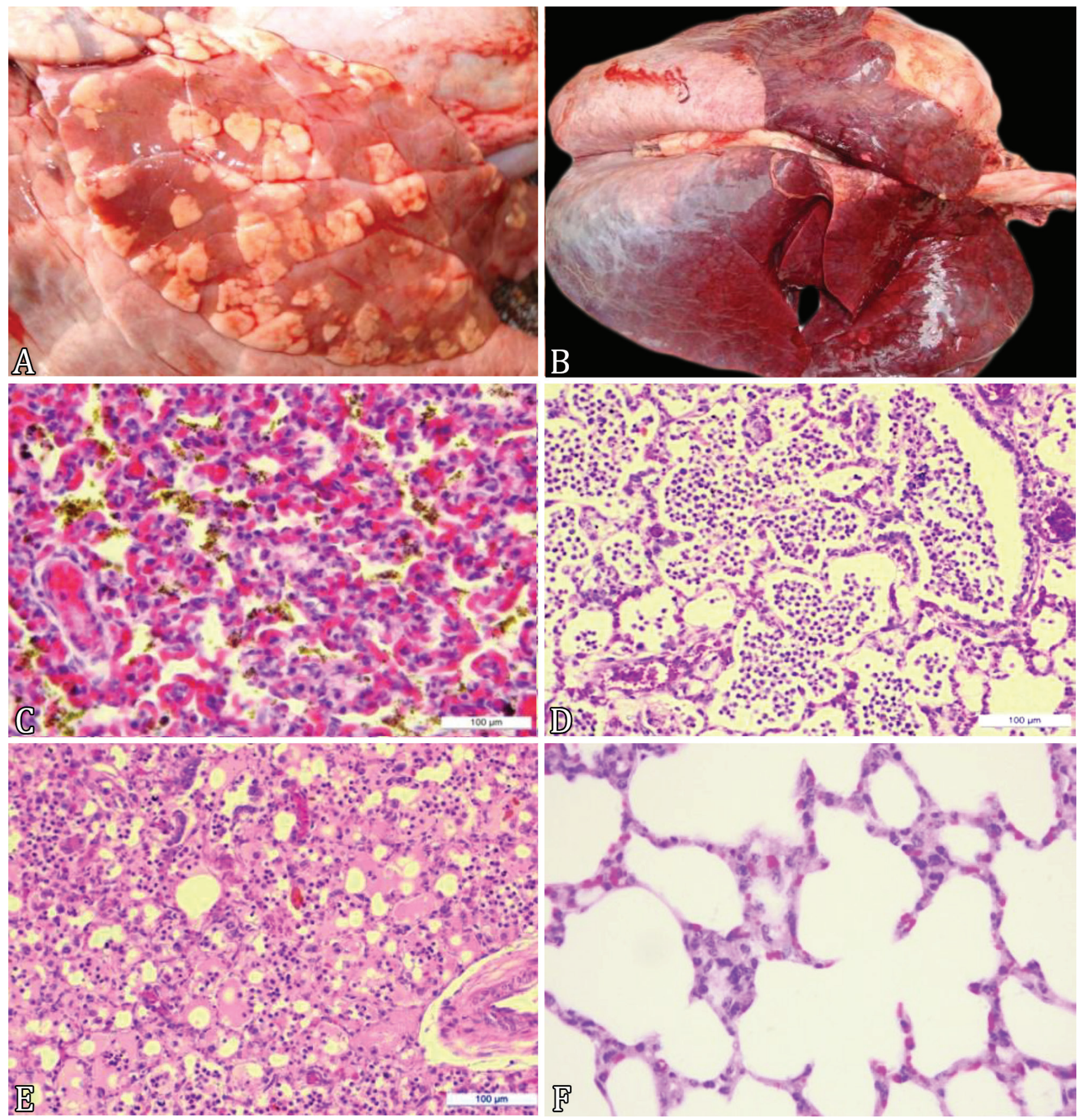

Fig.3. Changes observed in the lungs of cloned and control neonates. (A) Areas of atelectasis, cloned calf. (B) Pneumonia, areas of consolidation, note the reduced functional pulmonary area. (C) Marked infiltration of inflammatory cells, presence of meconium inside the alveoli, cloned calf. HE, obj.10x. (D) Marked infiltration of inflammatory cells, cloned calf. HE, obj.10x. (E) Marked pulmonary edema, cloned calf. HE, obj.10x. (F) Normal appearance of the pulmonary alveoli, control calf. HE, obj.10x. 
microscopic findings, congestion was observed because it is related to congestive heart failure, liver cirrhosis, or other causes of increased retrograde pressure (Thomson 1998). This fact is consistent with that observed in the present study, which sometimes revealed thickening of the right ventricle and liver degeneration. Hemorrhage and hemosiderosis are likely due to prolonged congestion (Thomson 1998). Little evidence of white pulp was also observed in the spleens of cloned animals; and previous reports showed marked follicular rarefaction in a 50-day-old calf (Renard et al. 1999), in addition to white pulp hypoplasia and changes in other lymphoid organs in cloned calves (Santos et al. 2010).

In the kidneys of cloned calves, brown granules, proliferation of connective tissue, fibrosis, tubular degeneration, necrosis, and lymphocytic and plasmacytic infiltrates were observed. Several renal lesions have been reported in cloned animals, including cystic formations associated with dilated tubules (Santos et al. 2010), and severe bilateral hydronephrosis associated with obstructive lesions in the urinary system (Wells et al. 1997, Rhind et al. 2003). The presence of brownish granules inside the cells of the cortical and medullary tubules was observed only in the kidneys of cloned calves. It was not possible to accurately identify this pigmentation; however, it is known that the observed pigment does not originate from the accumulation of bile pigments, iron, hemosiderin or glycogen, as no characteristic coloring was evident with the techniques used (i.e., Hall, Perls, and PAS, respectively). Okano et al. (2003) described vacuolization of the renal tubular epithelium in aborted calves that exhibited positive staining using the PAS method. In the present study, PAS staining did not characterize the granules observed in the tubular epithelium. However, there was positive staining in the collecting tubules of the renal cortex using this method. The granules observed exhibited many characteristics similar to those of lipofuscin; however, due to the techniques used in this study, such confirmation was not possible. Although staining for lipofuscin identified the granules, it was not with the expected intensity. Lipofuscin can accumulate within epithelial cells of the renal tubules in older cattle in the form of fine golden granules (Zachary \& McGavin 2012). Macroscopically, lipofuscin is evident as brown streaks in the renal cortex, similar to the macroscopic findings reported here. Akagi et al. (2003) described a kidney injury as a deposit of lipofuscin in the tubular epithelium of a cloned calf that died at 13 days of age. It is believed that the presence of such granules warrant further analysis in attempts to determine the origin of the pigment and its relationship with observed renal changes.
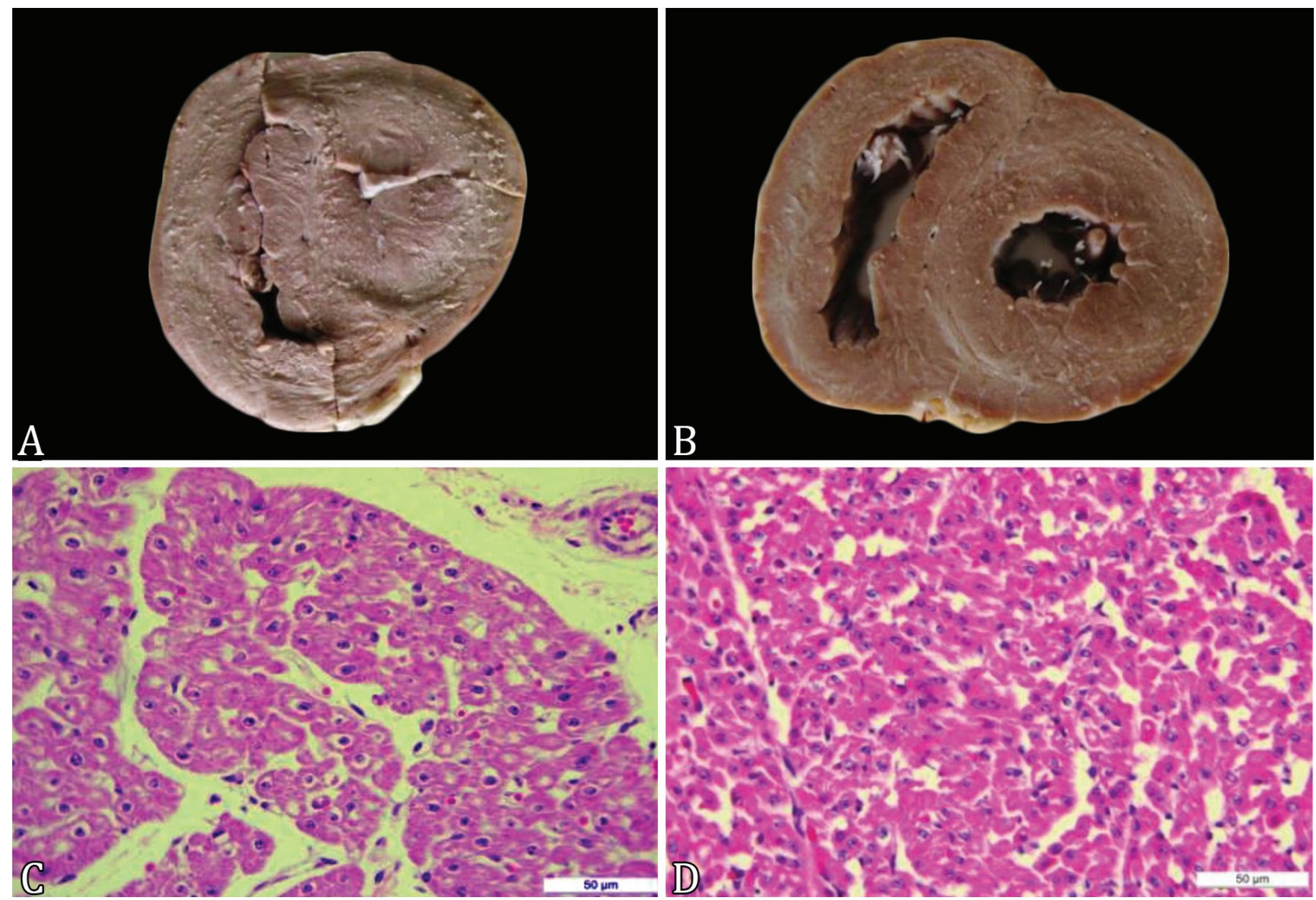

Fig.4. Changes observed in the heart of cloned neonates and controls. (A) Cardiac muscle hypertrophy, cloned calf. (B) Normal organ characteristic, control calf. (C) Vacuolization of cardiomyocytes, cloned calf. HE, obj.40x. (D) Note less vacuolization and spacing of cardiomyocytes, control calf. HE, obj.40x. 
The lungs were the organs with the highest number of alterations (virtually all cloned calves exhibited some finding in the lungs). In the ING, the most common finding was atelectasis, which is consistent with previous studies (Santos et al. 2010, Maiorka et al. 2015). Atelectasis is characterized by incomplete expansion of the alveoli and can be caused by several factors, including neonatal asphyxia, pulmonary hypertension, and aspiration of amniotic fluid or meconium (Dungworth 1993). The occurrence of atelectasis was found to be determinant of the animals' survival beyond the immediate

Table 3. Microscopic findings in spleen, liver and kidneys of cloned and control calves that died in the neonatal period

\begin{tabular}{|c|c|c|c|c|}
\hline \multirow{2}{*}{ Organ/Findings } & \multicolumn{3}{|c|}{ Clones $(n=41)$} & \multirow{2}{*}{ Control $(n=4)$} \\
\hline & ING $(n=25)$ & LNG $(n=16)$ & Total & \\
\hline \multicolumn{5}{|l|}{ Spleen } \\
\hline Reduction in white pulp & $14(58 \%)$ & $5(31 \%)$ & $19(48 \%)$ & 0 \\
\hline Hemorrhage & $11(46 \%)$ & $4(25 \%)$ & $15(38 \%)$ & 0 \\
\hline Congestion & $1(4 \%)$ & $8(50 \%)$ & $9(23 \%)$ & 0 \\
\hline Hemosiderosis & 0 & $2(13 \%)$ & $2(5 \%)$ & 0 \\
\hline Histiocytic infiltrate & 0 & $1(6 \%)$ & $1(3 \%)$ & 0 \\
\hline No lesion & $7(29 \%)$ & $4(25 \%)$ & $11(28 \%)$ & $4(100 \%)$ \\
\hline \multicolumn{5}{|l|}{ Liver } \\
\hline Well-defined lobular pattern & $25(100 \%)$ & $5(31 \%)$ & $30(73 \%)$ & $4(100 \%)$ \\
\hline Virtually imperceptible sinusoids & $25(100 \%)$ & $5(31 \%)$ & $30(73 \%)$ & $4(100 \%)$ \\
\hline Closed distance between portal spaces & $25(100 \%)$ & $9(56 \%)$ & $34(83 \%)$ & $4(100 \%)$ \\
\hline Cytoplasmic vacuolization of hepatocytes & $23(92 \%)$ & $12(75 \%)$ & $35(85 \%)$ & $3(75 \%)$ \\
\hline Mild & $6(24 \%)$ & $9(56 \%)$ & $15(37 \%)$ & $2(50 \%)$ \\
\hline Moderate & $7(28 \%)$ & $1(6 \%)$ & $8(20 \%)$ & 0 \\
\hline Severe & $10(40 \%)$ & $2(13 \%)$ & $12(29 \%)$ & $1(25 \%)$ \\
\hline PAS negative & $10(40 \%)$ & $14(88 \%)$ & $24(59 \%)$ & $1(25 \%)$ \\
\hline PAS positive (accumulation of glycogen) & $15(60 \%)$ & $2(12 \%)$ & $17(41 \%)$ & $3(75 \%)$ \\
\hline Mild & $3(12 \%)$ & $2(13 \%)$ & $4(10 \%)$ & $1(25 \%)$ \\
\hline Moderate & $4(16 \%)$ & 0 & $3(7 \%)$ & $1(25 \%)$ \\
\hline Severe & $8(32 \%)$ & 0 & $8(20 \%)$ & $1(25 \%)$ \\
\hline Extramedullary hematopoiesis & $4(16 \%)$ & $4(25 \%)$ & $8(20 \%)$ & 0 \\
\hline Congestion & $2(8 \%)$ & $2(13 \%)$ & $4(10 \%)$ & 0 \\
\hline Hemorrhage & $5(20 \%)$ & 0 & $5(12 \%)$ & 0 \\
\hline Necrosis & $4(16 \%)$ & $1(6 \%)$ & $5(12 \%)$ & 0 \\
\hline Fibrin & $1(4 \%)$ & $1(6 \%)$ & $2(5 \%)$ & 0 \\
\hline Histiocytic infiltrate & $1(4 \%)$ & $1(6 \%)$ & $2(5 \%)$ & 0 \\
\hline Neutrophilic infiltrate & $1(4 \%)$ & $1(6 \%)$ & $2(5 \%)$ & 0 \\
\hline Duct proliferation & 0 & $1(6 \%)$ & $1(2 \%)$ & 0 \\
\hline Connective tissue proliferation & $1(4 \%)$ & 0 & $1(2 \%)$ & 0 \\
\hline Cholestasis & 0 & $1(6 \%)$ & $1(2 \%)$ & 0 \\
\hline No lesion & 0 & $3(19 \%)$ & $3(7 \%)$ & 0 \\
\hline \multicolumn{5}{|l|}{ Kidneys } \\
\hline Glomeruli with an embryonic aspect & $25(100 \%)$ & $11(69 \%)$ & $36(88 \%)$ & $4(100 \%)$ \\
\hline $\begin{array}{l}\text { Brownish granules within cortical tubule } \\
\text { cells }\end{array}$ & $25(100 \%)$ & $12(75 \%)$ & $37(90 \%)$ & 0 \\
\hline Mild & $8(32 \%)$ & $5(31 \%)$ & $13(32 \%)$ & 0 \\
\hline Moderate & $6(24 \%)$ & $5(31 \%)$ & $11(27 \%)$ & 0 \\
\hline Severe & $11(44 \%)$ & $2(13 \%)$ & $13(32 \%)$ & 0 \\
\hline Congestion & $8(32 \%)$ & $8(50 \%)$ & $16(39 \%)$ & 0 \\
\hline Hemorrhage & $1(4 \%)$ & 0 & $1(2 \%)$ & 0 \\
\hline Tubular dilation & $2(8 \%)$ & $3(19 \%)$ & $5(12 \%)$ & 0 \\
\hline Connective tissue proliferation & $2(8 \%)$ & 0 & $2(5 \%)$ & 0 \\
\hline Tubular degeneration & 0 & $2(13 \%)$ & $2(5 \%)$ & 0 \\
\hline Lymphocytic infiltrate & 0 & $2(13 \%)$ & $2(5 \%)$ & 0 \\
\hline Fibrosis & 0 & $1(6 \%)$ & $1(2 \%)$ & 0 \\
\hline Necrosis & 0 & $1(6 \%)$ & $1(2 \%)$ & 0 \\
\hline Plasmacytic infiltrate & 0 & $1(6 \%)$ & $1(2 \%)$ & 0 \\
\hline
\end{tabular}


neonatal period. The atelectasis observed in cloned animals could often be associated with pulmonary immaturity and deficiency in surfactant production (Prestes et al. 2009), which leads to chronic pulmonary hypertension. Meconium aspiration observed in several ING animals, and also previously reported in cloned calves (Maiorka et al. 2015), is another factor that may have contributed to the observed atelectasis. Meconium reacts with phospholipids present in the surfactant, which causes failures in this layer and, thus, leads to atelectasis (Bleul 2009). In LNG animals, the most striking finding in the lungs was pneumonia. Many animals that died in the late neonatal period presented with aspiration pneumonia (meconium or milk aspiration), diffuse peritonitis due to ruptured abomasal ulcer(s), umbilical conditions, and passive immunity transfer failure. Therefore, the occurrence of such pulmonary changes is often secondary to other conditions. In septicemia, it is common detachment of septic emboli, which may migrate to the lungs, causing severe pneumonia (Dungworth 1993). Other changes observed in the lungs, such as fibrin deposition, proliferation of type II pneumocytes, thickening of the septum, hyperplasia of type I pneumocytes, proliferation of connective tissue, and necrosis, are common findings in pneumonia and have also been previously reported (Hill et al. 2000, Li et al. 2005, Santos et al. 2010, Maiorka et al. 2015).
In the heart, the fibrillar adhesions observed between the pericardial sac and the epicardium were consistent with an initial condition of fibrinous pericarditis, which, in neonates, may be due to coliform infection acquired by umbilical route (Robinson \& Maxie 1993). Lesions suggestive of endocardiosis were observed only in the hearts of cloned animals. Endocardiosis refers to a proliferation of loose connective tissue in the valve(s), accompanied by deposition of glycosaminoglycan, with concomitant collagen degeneration in the fibrous valve (Robinson \& Maxie 1993). Lesions related to endocardiosis have not yet been described in cloned animals. A case of hydropericardium was also identified, a lesion previously reported in cloned calves (Maiorka et al. 2015). This change may be related to congestive heart failure; other common causes of hydropericardium include anasarca, emaciating diseases, and neoplasms (Robinson \& Maxie 1993). Hypertrophy of the right ventricle, previously described in cloned animals (Garry et al. 1996, Hill et al. 1999, Rhind et al. 2003, Santos et al. 2010), is attributed to congenital pulmonary hypertension (Hill et al. 1999, Rhind et al. 2003). An additional finding in the hearts of cloned calves in the present study was the persistence of foramen ovale and ductus arteriosus, which was also reported (Maiorka et al. 2015). Hematic cysts are generally not attributed to any specific lesion. However, in

Table 4. Microscopic findings in lungs and heart of cloned and control calves that died in the neonatal period

\begin{tabular}{|c|c|c|c|c|}
\hline \multirow{2}{*}{ Organ/Findings } & \multicolumn{3}{|c|}{ Clones $(n=41)$} & \multirow{2}{*}{ Control $(n=4)$} \\
\hline & ING $(n=25)$ & LNG $(n=16)$ & Total & \\
\hline \multicolumn{5}{|l|}{ Lungs } \\
\hline Inflammatory cell infiltration & $7(29 \%)$ & $15(44 \%)$ & $22(55 \%)$ & $3(75 \%)$ \\
\hline Histiocytic infiltration & $6(25 \%)$ & $10(63 \%)$ & $16(40 \%)$ & 0 \\
\hline Neutrophilic infiltration & $3(13 \%)$ & $13(81 \%)$ & $16(40 \%)$ & $2(50 \%)$ \\
\hline Lymphocytic infiltration & $1(4 \%)$ & $1(6 \%)$ & $2(5 \%)$ & $1(25 \%)$ \\
\hline Atelectasis & $16(67 \%)$ & $2(13 \%)$ & $18(45 \%)$ & 0 \\
\hline Pulmonary edema & $8(33 \%)$ & $6(38 \%)$ & $14(35 \%)$ & 0 \\
\hline Congestion & $6(25 \%)$ & $3(19 \%)$ & $9(23 \%)$ & $4(100 \%)$ \\
\hline Hemorrhage & $4(17 \%)$ & $3(19 \%)$ & $7(18 \%)$ & 0 \\
\hline Meconium & $10(42 \%)$ & $1(6 \%)$ & $11(28 \%)$ & 0 \\
\hline Milk & $6(25 \%)$ & $1(6 \%)$ & $7(18 \%)$ & $1(25 \%)$ \\
\hline Fibrin & $2(8 \%)$ & $3(19 \%)$ & $5(13 \%)$ & 0 \\
\hline Type II pneumocyte Proliferation & 0 & $3(19 \%)$ & $3(8 \%)$ & 0 \\
\hline Septal thickening & 0 & $3(19 \%)$ & $3(8 \%)$ & 0 \\
\hline Thrombus & $1(4 \%)$ & $2(13 \%)$ & $3(8 \%)$ & 0 \\
\hline Type I pneumocyte hyperplasia & 0 & $1(6 \%)$ & $1(3 \%)$ & $1(25 \%)$ \\
\hline Connective tissue proliferation & 0 & $1(6 \%)$ & $1(3 \%)$ & 0 \\
\hline Necrosis & 0 & $1(6 \%)$ & $1(3 \%)$ & 0 \\
\hline \multicolumn{5}{|l|}{ Heart } \\
\hline Vacuolization of cardiac fibers & $6(25 \%)$ & $5(31 \%)$ & $11(28 \%)$ & 0 \\
\hline Same spacing of cardiac fiber bundles & $10(42 \%)$ & $8(50 \%)$ & $18(45 \%)$ & 0 \\
\hline Histiocytic infiltration & $1(4 \%)$ & $3(19 \%)$ & $4(10 \%)$ & 0 \\
\hline Lymphocytic infiltration & $3(13 \%)$ & $3(19 \%)$ & $3(8 \%)$ & $1(25 \%)$ \\
\hline Neutrophilic infiltration & $1(4 \%)$ & 0 & $1(3 \%)$ & 0 \\
\hline Fibrin & $1(4 \%)$ & $1(6 \%)$ & $2(5 \%)$ & 0 \\
\hline Congestion & 0 & $1(6 \%)$ & $1(3 \%)$ & 0 \\
\hline Hemorrhage & 0 & $1(6 \%)$ & $1(3 \%)$ & 0 \\
\hline Adherence & 0 & $1(6 \%)$ & $1(3 \%)$ & 0 \\
\hline No lesion & $8(33 \%)$ & $7(44 \%)$ & $15(38 \%)$ & $3(75 \%)$ \\
\hline
\end{tabular}


the present study, they were observed only in cloned calves. As frequently observed in cloned calves (Santos et al. 2010, Maiorka et al. 2015), especially in animals with heart disease, it is likely that cloned animals develop heart disease with the formation of hematic cysts and persistence of the foramen ovale and ductus arteriosus.

Vacuolization of cardiomyocytes was observed in the present study. However, it was not possible to identify the origin of the vacuoles due to the preparation/storage method of the sample material, which was stored in formaldehyde, thus making specific staining (i.e., Sudan staining) impossible, which requires the material to be frozen. It is probably related to fatty degeneration, similar to the degeneration seen in the liver (Thomson 1998), and analogous to cardiac degeneration in animals from in vitro fertilization (Prestes et al. 2009). The greater spacing of cardiac fibers was an alteration observed in cloned animals to a higher degree than in the CG and is often associated with myocyte vacuolization. The implications of this greater spacing on the health of cloned animals remain unclear, and such reports were not found in the literature.

The increased mortality of newborn cloned calves might be due to an abnormal immunity, increasing the susceptibility to infections. In health calves, the immune system's development is complete at birth, although it is still immature (Cortese 2009). In fact, about half of the cloned calves evaluated here showed reduced spleen white pulp. This fact may had increased the risk for pneumonia and umbilical infection. Additionally, most cloned calves present failures during adaptation to extrauterine life, being commonly observed prostration, lethargy, absence of the suction reflex and meconium elimination (Birgel Junior et al. 2011). Furthermore, vascular disorders were reported in cloned calves (Maiorka et al. 2015), which was also evident herein. Another reason contributing for the high mortality rate in cloned animals in the present study is impaired kidney function. Most common lesions included presence of brown granules (probably lipofuscin), proliferation of connective tissue, fibrosis, tubular degeneration, necrosis, and lymphocytic and plasmacytic infiltrates.

\section{CONCLUSIONS}

The main causes of death among cloned calves that died in the immediate neonatal period were liver damage, characterized mainly by marked hepatic degeneration, and difficulties in adapting to extrauterine life, clinically demonstrated as respiratory difficulty and pathologically as pulmonary disease (more specifically atelectasis), which circumstantially contributed to the death of these animals.

In calves that experienced late neonatal death (i.e., LNG), the most notable finding was severe pneumonia, which in many cases was secondary to other concurrent diseases. It is believed that this type of pneumonia is a significant contributor to death.

Findings in the kidneys of cloned animals warrant further investigations to determine the origin of the granules inside the cortical tubules and their relationship with other abnormalities in these animals. These changes may be caused by changes in DNA methylation pattern(s), resulting in epigenetic changes in animal metabolism.

Conflict of interest statement.- There are no conflict of interests.

\section{REFERENCES}

Akagi S., Adachi N., Matsukawa K., Kubo M. \& Takahashi S. 2003. Developmental potential of bovine nuclear transfer embryos and postnatal survival rate of cloned calves produced by two different timings of fusion and activation. Mol. Reprod. Develop. 66(3):264-272. <https://dx.doi.org/10.1002/ mrd.10352><PMid:14502605>

Ao Z., Li Z., Wang X., Zhao C., Gan Y., Wu X., Zeng F., Shi J., Gu T., Hong L., Zheng E., Liu D., Xu Z., Wu Z. \& Cai G. 2019. Identification of amniotic fluid metabolomic and placental transcriptomic changes associated with abnormal development of cloned pig fetuses. Mol. Reprod. Dev. 86(3):278291. <https://dx.doi.org/10.1002/mrd.23102><PMid:30618166>

Barreto R.S.N., Miglino M.A., Meirelles F.V., Visintin J.A., Silva S.M., Burioli K.C., Fonseca R., Bertan C., Assis Neto A.C. \& Pereira F.T.V. 2009. Caracterização da fusão caruncular em gestações naturais e de conceptos bovinos clonados. Pesq. Vet. Bras. 29(10):779-787. <https://dx.doi.org/10.1590/S0100736X2009001000001>

Birgel Junior E.H., Meirelles F.V., Komninou E.R., Nunes M.T., Pogliani F.C., Neto P.F., Yasuoka M.M., Pimentel J.R.V., Kubrusly F.S. \& Miglino M.A. 2011. Clinical disorders observed during the first 30 days of life of cloned Zebu calf. Acta Vet. Sci. 39(supl.1):s243-s252.

Bleul U. 2009. Respiratory distress syndrome in calves. Vet. Clin. N. Am., Food Anim. Pract. 25(1):179-193. <https://dx.doi.org/10.1016/j. cvfa.2008.10.002><PMid:19174288>

Bressan F.F., Fantinato-Neto P., Andrade G.M., Sangalli J.R., Sampaio R.V., Silveira J.C., Perecin F. \& Meirelles F.V. 2015. Challenges and perspectives to enhance cattle production via in vitro techniques: focus on epigenetics and cell-secreted vesicles. Ciência Rural 45(10):1879-1886. <https:// dx.doi.org/10.1590/0103-8478cr20141294>

CFMV 2013. Guia Brasileiro de Boas Práticas em Eutanásia em Animais: conceitos e procedimentos recomendados. Conselho Federal de Medicina Veterinária, Brasília, 62p.

Chavatte-Palmer P., Heyman Y., Richard C., Monget P., Lebourhis D., Kann G. \& Chilliard Y. 2002. Clinical. hormonal and hematologic characteristics of bovine calves derived from nuclei from somatic cells. Biol. Reprod. 66(6):1596-1603. <https://dx.doi.org/10.1095/biolreprod66.6.1596> $<$ PMid:12021036>

Cortese V.S. 2009. Neonatal immunology. Vet. Clin. North Am., Food Anim. Pract. 25(1):221-227. <https://dx.doi.org/10.1016/j.cvfa.2008.10.003> <PMid:19174291>

De Sousa P.A., King T., Harkness L., Young L.E., Walker S.K. \& Wilmut I. 2001. Evaluation of gestational deficiencies in cloned shep fetuses and placentae. Biol. Reprod. 65(1):23-30.<https://dx.doi.org/10.1095/biolreprod65.1.23> $<$ PMid:11420219>

Dungworth D.L. 1993. The respiratory system, p.577-613. In: Maxie M.G. (Ed.), Jubb, Kennedy and Palmer's Pathology of Domestic Animals. 4th ed. Academic Press, San Diego.

Garry F.B., Adams R., McCann J.P. \& Odde K.G. 1996. Postnatal characteristics of calves produced by nuclear transfer cloning. Theriogenology 45(1):141152. <https://dx.doi.org/10.1016/0093-691X(95)00363-D>

Hill J.R., Burghardt R.C., Jones K., Long C.R., Looney C.R., Shin T., Spencer T.E, Thompson J.A., Winger Q.A. \& Westhusin M.E. 2000. Evidence for placental abnormality as the major cause of mortality in first- trimester somatic cell cloned bovine fetuses. Biol. Reprod. 63(6):1787-1794. <https://dx.doi. org/10.1095/biolreprod63.6.1787><PMid:11090450>

Hill J.R., Roussel A.J., Cibelli J.B., Edwards J.F., Hooper N.L., Miller M.W., Thompson J.A., Looney C.R., Westhusin M.E., Robl J.M. \& Stice S.L. 1999. Clinical and pathologic features of cloned transgenic calves and fetuses (13 case studies). Theriogenology 51(8):1451-1465. <https://dx.doi. org/10.1016/s0093-691x(99)00089-8> <PMid:10729073> 
Ibtisham F., Fahd Qadir M.M., Xiao M. \& An L. 2017. Animal cloning applications and issues. Russ. J. Genet. 53(9):965-971. <https://dx.doi.org/10.1134/ S102279541709006X>

Kato Y., Tani T., Sotomaru Y., Kurokawa K., Kato J.-Y., Doguchi H., Yasue H. \& Tsunoda Y. 1998. Eight calves cloned from somatic cells of a single adult. Science 282(5396):2095-2098. <https://dx.doi.org/10.1126/ science.282.5396.2095><PMid:9851933>

Kiefer H., Jouneau L., Campion É., Rousseau-Ralliard D., Larcher T., MartinMagniette M.L., Balzergue S., Ledevin M., Prézelin A., Chavatte-Palmer P., Heyman Y., Richard C., Le Bourhis D., Renard J.P. \& Jammes H. 2016. Altered DNA methylation associated with an abnormal liver phenotype in a cattle model with a high incidence of perinatal pathologies. Sci. Rep. 6:38869. <https://dx.doi.org/10.1038/srep38869><PMid:27958319>

Lee R.S.F., Peterson A.J., Donnison M.J., Ravelich S., Ledgard A.M., Li N., Oliver J.E., Miller A.L., Tucker F.C., Breier B. \& Wells D.N. 2004. Cloned cattle fetuses with the same nuclear genetics are more variable than contemporary halfsiblings resulting from artificial insemination and exhibit fetal and placental growth deregulation even in the first trimester. Biol. Reprod. 70(1):1-11. <https://dx.doi.org/10.1095/biolreprod.103.020982><PMid:13679311>

Li S., Li Y., Du W., Zhang L., Yu S., Dai Y., Zhao C. \& Li N. 2005. Aberrant gene expression in organs of bovine clones that die within two days after birth. Biol. Reprod. 72(2):258-265. <https://dx.doi.org/10.1095/ biolreprod.104.029462><PMid:15240423>

Maiorka P.C., Favaron P.O., Mess A.M., Santos C.R., Alberto M.L., Meirelles F.V. \& Miglino M.A. 2015. Vascular alterations underlie developmental problems manifested in cloned cattle before or after birth. PLoS One 10:e106663. <https://dx.doi.org/10.1371/journal.pone.0106663><PMid:25584533>

Mee J.2011. Bovine neonatal survival: is improvement possible? Epidemiology of bovine perinatal mortality incidence of perinatal mortality. WCDS Adv. Dairy Technol. 23:161-174.

Okano W., Bracarense A.P.F.R.L., Reis A.C.F. \& Alfieri A.A. 2003. Achados histológicos em fetos bovinos abortados e não abortados. Arq. Bras. Med. Vet. Zootec. 55(2):223-225. <https://dx.doi.org/10.1590/S010209352003000200016>

Palmieri C., Loi P., Ptak G. \& Della Salda L. 2008. Review paper: a review of the pathology of abnormal placentae of somatic cell nuclear transfer clone pregnancies in cattle, sheep, and mice. Vet. Pathol. 45(6):865-880. <https://dx.doi.org/10.1354/vp.45-6-865><PMid:18984789>

Panarace M., Aguero J.I., Garrote M., Jaurengui G., Segovia A., Cané L., Gutiérrez J., Marfil M., Rigali F., Pugliese M., Young S., Lagioia J., Garnil C., Pontes J.E.F., Ereno Junio J.C., Mower S. \& Medina M. 2007. How healthy are clones and their progeny: 5 years of field experience. Theriogenology 67(1):142-151. <https://dx.doi.org/10.1016/j.theriogenology.2006.09.036> $<$ PMid:17067665>
Prestes N.C., Piagentini M., Moya-Araujo C.F. \& Rocha N.S. 2009. Histopathologic characterization of "IVP" calves that during the perinatal period - cases report. Ars Vet. 25(1):38-41. <https://dx.doi.org/10.15361/21750106.2009v25n1p038-041>

Renard J.P., Chastant S., Chesné P., Richard C., Marchal J., Cordonnier N., Chavatte P. \& Vignon X. 1999. Lymphoid hypoplasia and somatic cloning. Lancet 353(9163):1489-1491. <https://dx.doi.org/10.1016/S01406736(98)12173-6><PMid:10232316>

Rhind S.M., King T.J., Harkness L.M., Bellamy C., Wallace W., De Sousa P. \& Wilmut I. 2003. Cloned lambs: lessons from pathology. Nat. Biotechnol. 21(7):744745. <https://dx.doi.org/10.1038/nbt0703-744><PMid:12833090>

Robinson W. F. \& Maxie M.G. 1993. The cardiovascular system, p.1-43. In: Maxie M.G. (Ed.), Jubb, Kennedy and Palmer's Pathology of Domestic Animals. 4th ed. Academic Press, San Diego.

Santos C.R., Randi F., Miglino M.A., Meirelles F.V. \& Maiorka P.C. 2010. Patologia de neonatos bovinos originados por meio da técnica de transferência nuclear de células somáticas clonagem. Braz. J. Vet. Res. Anim. Sci. 47(6):447-453. <https://dx.doi.org/10.11606/issn.1678-4456.bjvras.2010.26806>

Taneja M., French R., Levine H., Tauro-Miller D. \& Yang X. 2001. Clinical and pathological status of cloned calves born pre-term. Theriogenology 55:293.

Thomson R.G. 1998. Alterações histopatológicas, p.251-256. In: Patologia Geral Veterinária. 2를 ed. Guanabara Koogan, Rio de Janeiro.

Wells D.N., Misica P.M., Day T.A.M. \& Tervit H.R. 1997. Production of cloned lambs from an established embryonic cell line: a comparison between in vivo- and in vitro-matured cytoplasts. Biol. Reprod. 57(2):385-393. <https://dx.doi.org/10.1095/biolreprod57.2.385><PMid:9241054>

Wilmut I., Schnieke A.E., Mcwhir J., Kind A.J. \& Campbell K.H.S. 1997. Viable offspring derived from fetal and adult mammalian cells. Nature 385(6619):810813. <https://dx.doi.org/10.1038/385810a0><PMid:9039911>

Wilson J.M., Williams J.D., Bondioli K.R., Looney C.R., Westhusin M.E. \& McCalla D.F. 1995. Comparison of birth weight and growth characteristics of bovine calves produced by nuclear transfer (cloning), embryo transfer and natural mating. Anim. Reprod. Sci. 38(1/2):73-83. <https://dx.doi. org/10.1016/0378-4320(94)01353-N>

Wiltbank M.C., Baez G.M., Garcia-Guerra A., Toledo M.Z., Monteiro P.L., Melo L.F., Ochoa J.C., Santos J.E. \& Sartori R. 2016. Pivotal periods for pregnancy loss during the first trimester of gestation in lactating dairy cows. Theriogenology 86(1):239-253. <https://dx.doi.org/10.1016/j. theriogenology.2016.04.037><PMid:27238438>

Zachary J.F. \& McGavin M.D. 2012. The urinary system, p.38-39. In: Ibid. (Eds), Pathologic Basis of Veterinary Disease. 5th ed. Elsevier, Missouri. 